\title{
The Role of Knowledge in the Immigrant Entrepreneurial Process
}

\author{
Pedro Calero Lemes \\ University of Las Palmas de Gran Canaria \\ School of Tourism in Lanzarote. Rafael Alberti, 50. 35507, Lanzarote, Spain \\ E-mail: pcalero@daea.ulpgc.es \\ Desiderio J. García Almeida \\ University of Las Palmas de Gran Canaria \\ 35017 Las Palmas de Gran Canaria, Spain \\ E-mail: dgarcia@dede.ulpgc.es \\ Esther Hormiga (Corresponding author) \\ Departament of Economics and Business Management, University of Barcelona \\ Diagonal 690. 08034 Barcelona \\ Telf. +34934020135Fax+344024580 E-mail: ehormiga@ub.edu
}

Received: October 25, $2010 \quad$ Accepted: November 8, $2010 \quad$ DOI: 10.5430/ijba.v1n1p68

\begin{abstract}
This work analyses entrepreneurship process in the immigration context from a new perspective: the knowledge-based view. The central axis addresses the construction and explanation of a model that includes immigrants' knowledge sources and geographical origin as well as their relationship with the generation of sustainable competitive advantages. As possible geographical contexts for immigrants' knowledge, this study focuses on the country of origin, the host country, and the migration process, including transit countries. Regarding knowledge sources, various ways are explored: formal education and other codified sources, experience, networks, and institutions. This article provides a valuable and unique discussion of a new model in order to understand immigrant entrepreneurship process using a new perspective.
\end{abstract}

Keywords: Immigrant entrepreneur, Knowledge, Competitive advantage, New ventures

\section{Introduction}

In many developed societies, there has been increasing interest in the study of immigrants as a significant social and economic phenomenon. One of the reasons is their traditional dynamism in the creation of firms as an alternative to unemployment and their involvement in the identification and exploitation of opportunities. On that line, one topic in the analysis of immigrant entrepreneurs focuses on the factors of success that characterize this group of entrepreneurs. Specially, in order to ensure and maintain their levels of entrepreneurial initiatives.

Moreover, while the knowledge-based view of the firm has generated many scientific works on business management, its application in the field of entrepreneurship has, surprisingly, been very limited. However, the concepts and models that have been based on knowledge-based theoretical perspectives are extremely useful to provide an understanding and explanation of certain key factors in the study of entrepreneurs (e.g., Wiklund \& Shepherd, 2003; West III \& Noel, 2009). Thus, the specificities of immigrant entrepreneurs may be better understood with the application of certain ideas from the knowledge-based perspective. Immigrant entrepreneurs have a particular knowledge sources that characterize them and can be different from the sources shared by the purely national entrepreneurs.

This work aims to construct a model that explains the role of the knowledge sources characterizing immigrant entrepreneurs in a territory in the successfully implementing entrepreneurial projects. It also addresses the geographical implications of the territory in the development of strategic knowledge and the generation of competitive advantages. To that end, the first section relates the knowledge perspective and entrepreneurship and the second reviews the basic 
approaches of the immigrant entrepreneur in this context. That is followed by the proposal and discussion of a model that analyzes the relationship between knowledge and the immigrant entrepreneur. The work ends with the most relevant conclusions of the analysis.

\section{Knowledge and newly created firms}

In recent years, the literature on business management, and mainly strategic approaches, has highlighted the role of knowledge in obtaining and maintaining competitive advantages and higher performance (Eisenhardt \& Santos, 2001). One of the main reasons is the difficulty to imitate the knowledge-based resources (e.g., Grant, 1996; Teece, 1998; Nonaka \& Teece, 2001). Tsoukas and Vladimirou (2001) argued that knowledge is the capacity of individuals to make distinctions or judgments regarding a context and/or theory but, in general, the key role of innovation in business management has been explicitly recognized in the models of knowledge management by means of the knowledge creation processes (e.g., Armistead, 1999; Argote et al., 2003). However, the direct application of knowledge-based concepts and models to the study of entrepreneurship has been much more limited. In that regard, the relationship between knowledge and new venture creation can be considered fundamental given how important the total perspectives and knowledge accumulated by the entrepreneurial team are in the recognition of opportunities and the start-up of the new business project.

In the organizational environment, there has been emphasis on the relevance of knowledge to predict more accurately the nature and commercial potential of changes in the environment, to recognize and exploit new opportunities and to execute appropriate strategic and operational actions (Cohen \& Levinthal, 1990; Wiklund \& Shepherd, 2003). Those assumptions can be directly extrapolated to the creation of new enterprises. That is because the entrepreneur's knowledge, especially tacit knowledge, permits him/her to identify opportunities in the environment and draw up and develop a business idea that makes it feasible to exploit the opportunity. In that regard, some lines of research in the recent literature on firm creation argue the transcendental importance of knowledge in the detection and exploitation of business opportunities (Shane, 2000; Davidsson \& Honig 2003; West III \& Noel 2009).

The knowledge diffusion theory assume that knowledge-rich contexts are more prone to entrepreneurial behavior (Audretsch \& Keilbach, 2007) because of the business opportunities generated in uncertain environments (Álvarez \& Barney, 2005). Clerq and Arenius (2006) directly address the creation of a new business project and raise the role of knowledge to the trust generated in the entrepreneur's typical capabilities to start up a new venture. Those authors call that concept self-efficacy and focus on the fact that an entrepreneur's base of knowledge and competences together with the possibility of access to other individuals' knowledge, especially via networks, induces entrepreneurs to start up a firm. In this line, West III and Noel (2009) state that knowledge-based resources are fundamental in new enterprises because they constitute the first type of resource that provides the initial source of competitive advantage and manage the development of other important resources.

\section{Knowledge in new ventures created by immigrants}

The arrival of immigrants to economically developed societies has increased in the last two decades with the development of transport systems and improved communications. This fact has made the economic impact of the activity of immigrants in developed societies a topic of great interest. Many individuals decide to emigrate searching a supposedly better economic situation but many of them have serious difficulties to enter in the labor market. While some firms use immigrant labor because of the lower salaries, and in some cases because of professional qualifications, the immigrant labor market restricts the possibility of employment and the chances of being hired in certain sectors. That problem is exacerbated in times of economic recession. As the consequence of factors like cultural baggage or previous experience, some individuals who decide to emigrate opt for entrepreneurship after identifying opportunities that are unexploited in the host societies and perceive that it could generate high incomes.

In previous studies on immigrant entrepreneurial process, the availability of information is one of the resources with greatest impact on the success of new enterprises created by immigrants (Deakins et al., 1997; Basu, 1998), and some authors include knowledge when addressing those resources (Sriram et al., 2007). In that regard, the immigrant entrepreneur has a bundle of knowledge stemming from the experience of the immigration process, in which the individual has been through international experiences and situations that have provided him with knowledge that differs from that of most native entrepreneurs.

Because of the lack of studies following this line, this work considers not only the immigrants' accumulated knowledge stemming from geographical and social peculiarities, but also its potential to generate sustainable competitive advantages for the new venture in the host country. Thus, the aim of this paper is make a reflection on the key role played by the immigrants' distinctive knowledge in the firm creation process. The model displayed below -see figure 1- 
shows, on the one hand, that the immigrant entrepreneur's accumulatedknowledge may come from different sources such as the networks and, on the other hand, it may have different origins. One peculiarity of this type of entrepreneur is the origin of their knowledge. It could be acquired, whether in the home country, the host country or transit countries and this is a characteristic that already gives immigrant entrepreneurs a differential value. However, that accumulated knowledge can neither have value nor materialize in a successful business initiative if it does not provide the knowledge required to successfully create and manage a firm in an economic sector in the host country. Furthermore, the knowledge possessed by immigrants has the potential to generate sustainable competitive advantages in new ventures, and therefore it could be the basis to obtain a superior performance. The following pages examine the elements contemplated in the proposed model, highlighting the aspects related to the knowledge generated and accumulated by immigrant entrepreneurs that may differentiate them from native entrepreneurs in the process of knowledge generation and application.

$<$ Figure 1 about here $>$

\subsection{Geographical origin of the immigrant entrepreneur's knowledge}

Some of the arguments presented so far, such as the potential relationship between the entrepreneur's knowledge and the competitive advantage of the new venture, can undoubtedly be applied to both immigrant and native entrepreneurs. However, there is a basic differentiating element in the immigrant entrepreneurs' generation and acquisition of that knowledge, namely, the geographical origin. As shown figure 1, the place where the new entrepreneur acquires that knowledge could be in the home country, the host country or in the intermediate or transition processes.

\subsubsection{Knowledge acquired in the home country}

Firstly, the entrepreneur has the knowledge that has accumulated in his country of origin from infancy to emigration. Depending on the moment that individual decides to leave the home country, he will have more or less time to accumulate knowledge there. Thus, immigrants will import experience, training and some contacts from his home country that could be useful in creating their own firm in the host country (García Rodríguez et al., 2005). In fact, on many occasions individuals consider that firm creation is the only valid option for application of that knowledge due to the possible barriers in the labor market. In many cases, immigrants have access and knowledge of the markets or industries in their home countries, which enable them to establish commercial links (Rath, 2007) and take advantage of international commercial networks. The establishment of those networks is usually a much more complicated task for native entrepreneurs should they wish to establish commercial relations with those countries (García Rodríguez et al., 2005).

\subsubsection{Knowledge acquired in the host country}

Secondly, knowledge is also acquired by the individual in the host country and will be the result of his contact with the new territory, its inhabitants, culture and institutions. One factor that is important to new venture creation by immigrants is the length of time that they have lived in the host country: that time is essential to learn and to obtain information and social resources. In other words, it is fundamental accumulating experience in the host country in order to make the move into business. The necessary knowledge may be acquired without discounting other sources such as education or immigrant networks (Raijman 2001). Accordingly, the knowledge acquired in the host country will be the key to the business expansion, with some authors stating that the firms owned by immigrants who restrict themselves to links with their ethnic community will not be able to expand (Sequeira \& Rasheed, 2006). In fact, immigrants find themselves in a more complicated situation when they wish to access a new market but do not have previous knowledge and experience (Clydesdale, 2008). In other words, greater knowledge of the host society will provide the new firm with more possibilities of growth. According to Altinay and Altinay (2006), the immigrant entrepreneurs best adapted and integrated in the host country's society will have greater probabilities of being more competitive, and that is achieved by improving skills in the host country's language or human resources management.

\subsubsection{Knowledge acquired via intermediate or transition processes}

Finally, there is the knowledge acquired in the process of transition between one country and the other. That transition process would involve all the knowledge obtained in intermediate destinations between departure from the home country and arrival in the country where the firm has been constituted. Thus, the individual was able to pass through a series of countries or regions before deciding to locate in the country where he has created the new venture. In that regard, knowing two or more countries and, therefore, different environments, will enable the individual to exploit that knowledge by being able to apply it to the entrepreneurial activity by means of aspects such as opportunity detection or management techniques. The most common form is the known ethnic enclave where immigrants and immigrant businesses congregate. Some immigrants posses what Rusinovic (2008b) calls cultural capital, which would include 
command of two or more languages, knowledge of foreign markets, and in which international experience is one of the keystones of conducting transnational businesses.

Apart from that knowledge, whose origin is neither of the reference countries, there is also knowledge that will be acquired in the actual immigration process or by being an immigrant and that overlaps with other knowledge. There is knowledge that cannot be attributed to either the home or the host country because it is a direct consequence of the migration process. As Figure 1 shows, there is knowledge which, despite being acquired in the home country, is a result of the immigration process. In that case, it would comprise all the information and perspectives that the entrepreneur has gathered and captured before leave his/her country. This knowledge is usually obtained by the relationships with people in the host country or through contacts in the home country with individuals from the host country (e.g. The knowledge of a good city or area favorable for establishing a specific type of business). On the other hand, there is all the knowledge that, despite having been obtained in the host country, is a consequence of contact and relations with individuals in the entrepreneur's country of origin. Immigrant entrepreneurs' access to this information and knowledge is a result of their origins; therefore, despite being acquired in the home country, this knowledge may be considered to be at the intersection with the intermediate processes; in other words, results of the migration process (e.g. The knowledge of a compatriot supplier with a lower prices).

The focus on the geographical origin of the immigrants' knowledge introduces interesting perspectives to the analysis of successful firm creation by immigrants. By knowing two different realities, immigrants possess knowledge of their home countries' industry and markets, which represents an advantage that can be commercially exploited (Rath, 2007) due to the contacts and information acquired in the host country. That reality is demonstrated by Basu and Goswami (1999b) in their study of South-Asian entrepreneurs in the United Kingdom, where the links between the two countries can be exploited due to the economic information that those individuals handle and what is called multicultural knowledge. There is also a knowledge acquired in the host country that is later used in the home country in sectors such as tourism. That occurs in the case of Turkish-German entrepreneurs who know the likes and preferences of the German origin market and so can successfully serve those tourists. According to Pecoud (2002), to that end, they use families in their home countries and the social networks between the two countries.

\subsection{Relevant sources of the immigrant entrepreneur's knowledge}

To understand the mechanisms through which immigrant entrepreneurs obtain the knowledge for creating their new ventures is a key issue. Knowledge may be acquired from different sources such as education and other codified sources, experience, networks and institutions (Davidsson \& Honig 2003; Sequeira \& Rasheed 2006, Casson \& Della Giusta, 2007). With those four sources of knowledge and irrespective of the origins of those sources -home country, host country or intermediate processes- the entrepreneur will be able to accumulate the knowledge necessary to start up a new business initiative.

\subsubsection{Knowledge from formal education and codified sources}

According to the traditional literature in the entrepreneurship field, education is considered one of the principal components of human capital, which displays some peculiarities in the case of immigrants. Education is positively correlated with the ability to organize both the resources necessary for that start-up, and the general skills that permit advantageous entry into businesses (e.g., Borjas, 1986; Portes, 1987, Chaganti \& Greene, 2002; Raijman, 2001). It can influence the creation and success of new firms via the accumulation of knowledge (Davidsson \& Honig, 2003). In general, the literature has considered the positive impact of formal education on the development of entrepreneurial skills and on a greater ability to recognize opportunities and to better interpret market changes and, therefore, on success in business (Casson, 1991; Basu, 1998; Basu \& Goswami, 1999a; Altinay \& Altinay, 2006).

However, the influence of formal education, measured in years in education or the educational level achieved has been steeped in controversy. Altinay and Altinay (2006) show the existence of a positive relationship between education and business growth in the services sector but not in the specific case of commerce. In that regard, they consider that, for example, knowledge of the English language exercises greater influence than education on the successful start-up of a business (Altinay \& Altinay, 2006).

The analysis of the knowledge that immigrants acquire through formal education must be conducted with caution due to the heterogeneity of that group and the varying geographic and socioeconomic origins of its members. Low educational levels or little knowledge of the host country's language are usually cited as characteristics of this group although the previously mentioned heterogeneity means that it is a mistake generalized this assumption (Saxenian, 2006). However, this lack of basic knowledge has been assumed as one of difficulties for accessing to the labor market. Consequently they can turn to self-employment as the only way to overcome that obstacle and earn an acceptable income (Ley, 2006; 
Vinogradov \& Kolvereid, 2007). However, that might be considered a motivation to create a new venture but not for its growth. Immigrants with higher educational levels, such as university graduates, may encounter fewer problems when seeking well-paid jobs and, therefore, the creation of their own firms would not be so probable (Vinogradov \& Kolveried 2007). However, it is the immigrants with higher educational levels acquired in their home countries who find themselves most capable of creating enterprises (Beaujot et al., 1994), especially when they have been able to validate their qualifications in the host country. Thus, when an immigrant decides to change his country of residence, he encounters a series of difficulties to apply his knowledge in the host country. In that respect, the immigrant meets particularly significant barriers to being able to use in the labor market the human capital acquired through formal education in the home country. The possible reasons for that include the difficulty of validating qualifications in the host country or the problems of mastering the language. This prevents them from applying their knowledge in certain work and professional contexts; therefore, the better qualified opt for self-employment in order to be able to develop it (Tienda \& Raijam, 2004). In this case, firm creation is one way to appropriate the rents of knowledge acquired from formal education in the home country.

Moreover, immigrants who have received education in the host country are in an advantageous position. According to Beaujot et al. (1994), they acquire knowledge about the society in which they have decided to settle and are also still able to use the resources of their ethnic community. That competitive advantage enables them to recognize business opportunities and so they have more possibilities of success in their businesses and a greater dedication to their growth. This places them in a privileged situation to create successful innovative enterprises as opposed to those who are self-employed because they are excluded from the job market and their entrepreneurial orientation is toward the ethnic enclave and businesses with low economies of scale or business niches abandoned by the natives of the host country (Volery, 2007).

Apart from formal education and other classical modes of education, there is a related aspect to be considered as a possible source of knowledge for the immigrant entrepreneur. That aspect comprises all the books and publications about management or the sector in which the immigrant decides to start a new business. He/she can extract both strategic and operational knowledge from that source in order to approach the creation and development of the new enterprise. However, the fundamentally explicit or codified nature of that knowledge may limit its direct application although, in combination with other knowledge sources, the development of communications technology and the more widespread access to Internet, it permits the consolidation of this factor in the processes of new firm creation by immigrants.

\subsubsection{Knowledge derived from experience}

The experience of the entrepreneur or entrepreneurial team has been considered one of the most important sources of knowledge and a determining factor in the success and growth of newly created ventures (Basu \& Goswami, 1999b; Hart et al., 1995).

Two criteria are mainly used when classifying experience. The first differentiates the place where the experience was gained; whether the entrepreneur has worked in the same sector as that to which the new business belongs or in an activity or market not related to that of the new firm. The second criterion refers to the role played or the job held by the entrepreneur prior to the constitution of the new business. This criterion distinguishes between (Ekanem \& Wyer, 2007; Hormiga et al., 2008):

- Experience acquired through entrepreneur parents, who, in the case of immigrant families, aim to train their offspring as future entrepreneurs.

- $\quad$ Experience gained via employment, often within the ethnic community, and which may be in the sector in which a new firm is started, or experience acquired in another sector.

- Experience gained by being an entrepreneur at an earlier time and that is used as a reference framework for his/her behavior and expectations in starting a new firm.

The experience gained as an employee of other immigrant entrepreneurs in a certain sector is one important way of acquiring the necessary knowledge and skills to start one's own new venture (Shinnar \& Young, 2008; Danes et al., 2007; Saiz López, 2004). In other words, by means of already settled entrepreneurs, the ethnic group sometimes functions like a "business incubator" (Shinnar \& Young, 2008). In that regard, it is common practice for ethnic entrepreneurs to employ members of their own community: this would constitute a mechanism to acquire technical knowledge that will make it easier for those employees to start up new ventures (Herebert, 2004). Various studies have shown that most immigrant entrepreneurs trained in other firms as employees (Altinay \& Altinay, 2006); thus, the knowledge acquired about the market structure can help them to detect business opportunities (Levent et al., 2003). One example of knowledge transfer is found in immigrants who worked as cooks in restaurants owned by other members of their 
community and later started up their own restaurants, with some even becoming owners of the firms that employed them in the past (Levent et al., 2003).

In England, Chaudhry and Crick (2008) show that most first-generation entrepreneurs already had knowledge about the business when they entered and were consequently able to start a new firm much more quickly. In fact, some authors have come to consider that knowledge acquired from experience prior to starting a new venture is the most important factor within human capital in the process of firm creation (Davidsson \& Honig 2003; Deakins et al., 2007). Moreover, on many occasions, entrepreneurs that have previously started up businesses learn from their mistakes and, as the personal construction theory argues, they obtain knowledge through key informants such as suppliers, customers and ex-colleagues by means of trust relationships (Ekanem \& Wyer, 2007). Immigrant entrepreneurs often use their previous experience in starting up firms or use the technical knowledge acquired in previous jobs in the host country to start a new business initiative (Turan \& Kara, 2007).

\subsubsection{Knowledge derived from networks}

It is essential that immigrant entrepreneurs are able to open up to and exploit external knowledge (Clercq \&Arenius, 2006). The acquisition of information and knowledge by formal and informal networks is fundamental for all entrepreneurs although, in the case of immigrant entrepreneurs, there are some circumstances that make this phenomenon distinctive (Hackler \& Mayer, 2008). For example, some authors have demonstrated that the use of informal social networks by immigrants is more usual than formal networks (Basu, 1998; Fadahunsi et al., 2000). In a study of the Asian entrepreneurial community, Dhaliwal (2006) suggested that, even before going to public or private support institutions, immigrant entrepreneurs preferred to use their informal networks. Furthermore, when they turned to public or private institutions outside their community, for example, banks, they almost always preferred to be attended by compatriots.

The reciprocal relationships that occur within ethnic groups provide key information and knowledge to obtain certain assets essential to the development of the activity in the first months of the firm's life (Waldinger et al., 1990; Hammarstedt, 2001; Altinay \& Altinay, 2006; Volery, 2007), and may even facilitate access to the initial capital or to lower cost labor (Deakins et al., 2007). In this line, Basu (1998) highlights the importance of the specific immigrant networks as support for the development of new businesses by helping generate the infrastructure and resources necessary to implement those businesses (Aldrich \& Waldinger, 1990). Immigrant networks also enable the entrepreneurs to have knowledge about suppliers, customers and even co-ethnic products (Ram, 1994; Basu, 1998), and detection of opportunities as well as advice on issues related to business management (Deakins et al., 2007).

Another significant aspect refers to the diffusion and transmission of the knowledge produced within the network mainly due to the closeness of the members (Sorenson \& Singh, 2007). In particular, the knowledge exchanged between the members of ethnic groups is usually tacit. For example, the information about the aid that entrepreneurs need is usually based on personal contact, as Kalnins and Chung (2006) proposed after their study of the Gujarati. Those authors indicated that entrepreneurs possess knowledge of the community that is crucial to starting and consolidating businesses, thus improving the chances of survival. In that regard, networks as sources of knowledge assume a more active role in the case of the entrepreneur being an immigrant since most of the information about firm start-up and growth is often received via their ethnic networks (Jamal, 2005), which can provide access to flexible and privileged information (Levent et al., 2003)

Moreover, the possible competitive advantage derived from knowing at least two different realities -home and host countries- can encourage a transnational growth (Ley, 2006) with the immigrant's networks in both countries playing significant roles. Transnational growth tends to be oriented to products from the home country although it is becoming more widespread in other sectors, such as tourism. At this point, it is appropriate to return to the previously discussed topic of the geographical origin of the knowledge accumulated by the immigrant entrepreneur.

\subsubsection{Knowledge derived from institutions}

The last knowledge source refers to the knowledge acquired from institutions. Fadanhusi et al. (2000) state that a high proportion of immigrant entrepreneurs begin their business activity without turning to any institution for advice. The main reason is they consider unnecessary to turn to formal networks, such as those linked to the government, business associations, etc., to start up and expand their businesses. In fact, they are unaware of most of the support and consulting programs implemented by governments, as Constant and Shachmurove (2006) show for the case of Germany. Similarly, Basu (1998) finds that Asian entrepreneurs do not go to formal sources of advice since they have more trust in members of their families or ethnic community. That reluctance to use formal institutions means that immigrant entrepreneurs are not taking advantage of knowledge that could favor the growth and expansion of their businesses (Basu 1998). On that 
same line, immigrant entrepreneurs do not trust the financial entities either. Basu (1998) suggests that rapid-growth Asian firms in Britain use financial entities neither in their start-up nor in their expansion. However, in their study applied to the Asian community in Britain, Jones and Ram (2007) found that some official institutions were used more by immigrants than by native entrepreneurs. In that regard, Sequeira and Rasheed (2006) consider that, if immigrant entrepreneurs aim to expand their business, they must create weak links beyond the immigrant enclaves and, therefore, will turn to associations or organizations that are able to help.

Expanding the concept of institution, one of the key types of knowledge is about the environment of the host country, which permits immigrant entrepreneurs to exploit the opportunities offered by the host society. This section of the paper introduces North's (1991) concept of "institution", which includes the set of regulations, customs, traditions, codes of conduct and rules under which a society operates. When individuals emigrate, they are faced with institutions that differ, from both the formal and informal perspectives, from those in their home country. In the case of immigrant entrepreneurs, non-adaptation to the institutions of the host country often means being limited to the strong links with the ethnic community and, thus, as previously mentioned, prevented from expanding their business beyond that community. Therefore, immigrant entrepreneurs wishing to expand should know and understand the institutions of the host country in order to generate new links and networks (Sequeira \& Rasheed, 2006). Those arguments can partly be applied to second generation immigrant entrepreneurs who prefer not to be based on their communities when starting their businesses (Rusinovic, 2008a).

\subsection{Development of competitive advantages in immigrants'new ventures from the knowledge-based view of the firm}

Entrepreneurship is intimately connected with the appearance and adjustment of unique and idiosyncratic resources (Alvarez, 2003). The resource-based view underlines the relevance of heterogeneous firm assets in achieving a firm's sustainable competitive advantage, and these ideas have permeated the traditional view of competitive advantage which stresses the relevance of unique resources and capabilities in a firm. The basis or the potential to outperform rivals and to earn a persistently higher rate of profit (Grant, 2002) arises from these elements. In that sense, knowledge acquired by immigrants can become a valuable source of competitive advantage for their new ventures.

Since an external change creates opportunities for profit (Grant, 2002), the ability to identify and respond to opportunity lies in effective entrepreneurship (Rumelt, 1987) or innovative behavior by established firms. Based on the concepts of the resource dependence view and the idea of environmental enactment proposed by Pfeffer and Salancik (2003), individuals with a distinctive knowledge base can identify and have a better position to exploit opportunities in an industry. The relevance of information in the process of environmental enactment and decision-making proposed in the resource dependence framework (Pfeffer \& Salancik, 2003) support the strategic role that the knowledge possessed by immigrants can have in the development of new ventures with competitive advantages. This knowledge can also influence the speed of response by setting-up ventures before the locals or before established companies launch new products or implement new processes. And responsiveness also involves anticipating changes in the basis of competitive advantages over time (Grant, 2002), which a solid knowledge derived from different geographical contexts can provide. Therefore, immigrants could achieve first-mover advantages.

On the other hand, creativity and innovation are also classical sources of competitive advantage. According to Alvarez (2003), entrepreneurship shed some light into the process of how resources are discovered and recombined to provide more complex unique resources that lead to sustained competitive advantage, which is an aspect that has received scant attention in the strategic management field. Alvarez and Barney (2004) link the outcome of rent generation to entrepreneurial knowledge and the effective coordination of that knowledge in the entrepreneurial firm. As it has been previously discussed, knowledge generated and accumulated in the migration process can become the source of different approaches to manage a new venture or to create new products and processes which allow for achieving competitive advantages.

Regarding the orientation of the competitive advantage that immigrant's knowledge can generate, both types of generic advantages (cost and differentiation advantages) proposed by Porter (1985) can be achieved. Cost advantages can be generated because the immigrant knowledge can be critical to design new processes and products, have access to cheaper resources (e.g., human resources in their networks or access to inputs in their home countries) and possess a different managerial style or adapted to the new venture's staff developed from his/her international experience. On the other hand, immigrants can create products with intangible or tangible characteristics which are perceived as unique by a significant number of customers, due to their knowledge of different realities; hence the differentiation advantages would be achieved. The basis for this differentiation could stem from the focus on certain consumer groups (e.g., other immigrants), the understanding of the consumer and the buying decision process, the development of exotic products, etc. 
Another interesting dimension of the analysis of immigrants' knowledge and its relationship with competitive advantage is the sustainability issue. Since competitive advantage is subject to erosion by competitors, the existence of "isolating mechanisms" (Rumelt, 1984) is a key aspect to limit the ex-post equilibration of rents among firms. In that sense, the knowledge embedded in immigrants who have been exposed to many experiences in different countries can be considered complex or even "foreign" by local entrepreneurs or top managers in established firms in the host country. Thus, the causal ambiguity (Reed \& DeFillippi, 1990) embedded in knowledge accumulated in geographically- or culturally-distant countries reveals as a powerful deterrent to imitation by competitors, and it can sustain the competitive advantage achieved by immigrant entrepreneurs. Furthermore, the acquisition of that knowledge by competitors could require a long period of time, and so time compression diseconomies (Dierickx \& Cool, 1989) may operate.

\section{Conclusions}

This work has aimed to address the process of new venture creation by immigrants from the knowledge based view of the firm. The tools provided by that theoretical reflection contribute to enhancing the analysis of the creation and development of firms by one of the most dynamic groups in the start-up of new businesses.

This article focuses on proposing a model that addresses the role of knowledge in the immigrant entrepreneurial process. The model can be described in terms of three generic blocks: the geographical and circumstantial framework in which the knowledge is absorbed by immigrants; the sources or means by which the individual who has emigrated accumulates a bundle of knowledge; and the potential to develop sustainable competitive advantages from the immigrant entrepreneurs' accumulated knowledge. Moreover, we reflect on the importance of certain aspects which, although they have traditionally been addressed in a classic way in the field of entrepreneurship, have not been jointly studied in the analysis of the success of new ventures created by immigrants.

Through their experiences in life, immigrants can exploit opportunities in some segments of the environment which have not been recognized by native entrepreneurs since they lack the knowledge base required to overcome the strategic blindness to identify those opportunities. This same argument applies to innovation and creativity in some other cases. Competitive advantages based on cost savings or on differentiation can be achieved by applying distinctive knowledge and ways to do things.

Immigrants with previous experience in enterprise creation are usually in a more favorable position since they have accumulated knowledge in the creation and management of firms or have both tacit and explicit knowledge, whether of the job or of business, in the sector. That situation enables them to develop business activities with more guarantees in the host country sector. Immigrant entrepreneurs have often gained that experience with other entrepreneurs from the same ethnic community, permitting them to detect business opportunities, by functioning in the style of a "business incubator".

The origin of the knowledge in the specific context of the immigrant entrepreneur is also of outstanding relevance. Part of their accumulated knowledge is acquired in the home country while another is generated and transferred in the migration process or after arriving to the host country. First generation immigrants normally receive almost all their education and quite a lot of experience in their home countries. At this point, it is interesting to note that the individuals who emigrate are usually those who are best prepared (Dalziel, 2008) since those who they leave behind are going to depend on them. This might suggest that the individuals with a greater accumulation of knowledge and skills are the ones who emigrate and are also those with a greater tendency to take risks. Therefore, they would have the proper combination at their disposal to be successful in their businesses.

The migration process gives them knowledge from two different environments, providing them with competitive advantages over other entrepreneurs. They know the demand from customers with the same ethnic identity and, as they can learn about the rest of host customers. Moreover, they benefit from the so-called ethnic resources and can also take advantage of the knowledge accumulated by their families, or the accumulated knowledge about potential customers, suppliers, etc. the entrepreneurs with greater knowledge acquired in their home countries can introduce changes and generate innovations in important production sectors that can bring benefits to the sector. The knowledge accumulated in two different realities, combined with the networks generated in both environments, facilitates the implementation of transnational operations.

For many immigrant entrepreneurs, while the ethnic community represents vital aid in starting up a new enterprise, it is the links beyond that community that permit them to expand their business. This means that the knowledge acquired via immigrant networks is fundamental to the initiation of the business activity but the growth of this type of enterprise should derive from other networks or institutions beyond that community. 


\section{References}

Aldrich, H., and Waldinger, R. (1990). Ethnicity and entrepreneurship, Annual Review of Sociology, 16(1), 111-135.

Altinay, L.,and Altinay, E. (2006). Determinants of ethnic minority entrepreneurial growth in the catering sector, The Service Industries Journal, 26(2), 203-221.

Alvarez, S.A. (2003). Resources and hierarchies: Intersections between entrepreneurship and strategy. In Z.J. Acs, \& D.B. Audretsch (Eds.), Handbook of entreprenurship research. An interdisciplinary survey and introduction (pp.). Dordrecht: Kluwer Academic Publishers.

Alvarez, S.A., and Barney, J.B. (2004). Organizing rent generation and appropriation: Toward a theory of the entrepreneurial firm. Journal of Business Venturing, 19(5), 621-635.

Alvarez, S.A., and Barney, J.B. (2005). How do entrepreneurs organize firms under conditions of uncertainty? Journal of Management, 31(5), 776-793.

Audretsch, D.B., and Keilbach, M. (2007). The theory of knowledge spillover entrepreneurship. Journal of Management Studies, 44, 1242-1254.

Argote, L., McEvily, B., and Reagans, R. (2003). Managing knowledge in organizations: An integrative framework and review of emerging themes. Management Science, 49, 571-582.

Armistead, C. (1999). Knowledge management and process performance. Journal of Knowledge Management, 3 , 143-154.

Basu, A. (1998). An exploration of entrepreneurial activity among Asian small business in Britain. Small Business Economics, 10(4), 313-326.

Basu, A., and Goswami, A. (1999a). Determinants of South Asian entrepreneurial growth in Britain: a multivariate analysis. Small Business Economics, 13(1), 57-70.

Basu, A., and Goswami, A. (1999b). South Asian entrepreneurship in Great Britain: factors influencing growth. Journal of Entrepreneurial Behaviour \& Research, 5(5), 251-275

Beaujot, R., Maxim, P.S., and Zhao, J.Z. (1994). Self-employment among immigrants: a test of the blocked mobility hypothesis. Canadian Studies in Population, 21(2), 81-96.

Borjas, G.J. (1986). The self-employment experience of immigrants. Journal of Human Resources, 21(Fall), 485-506.

Brush, C.G., Greene, P.G., and Hart, M.M. (2001). From initial idea to unique advantage: The entrepreneurial challenge of constructing a resource base. Academy of Management Executive, 15, 64-78.

Casson, M. (1991). The Entrepreneur: An Economic Theory. Aldershot: Gower House.

Casson, M., and Della Giusta, M. (2007). Entrepreneurship and social capital. International Small Business Journal, 25(3), 220-244.

Chaganti, R., and Greene, P. (2002). Who are ethnic entrepreneurs? A study of entrepreneurs' ethnic involvement and business characteristics. Journal of Small Business Management, 40(2), 126-143.

Chaudhry, S., and Crick, D. (2004). The business practices of small Chinese restaurants in the UK: an exploratory investigation. Strategic Chance, 13(1), 37-49.

Clercq, D.D., and Arenius, P. (2006). The role of knowledge in business start-up activity. International Small Business Journal, 24(4), 339-358.

Clydesdale, G. (2008). Business immigrants and the entrepreneurial nexus. Journal of International Entrepreneurship, 6 , $123-142$.

Cohen, W.M., and Levinthal, D.A. (1990). Absorptive capacity: a new perspective on learning and innovation. Administrative Science Quarterly, 35, 128-152.

Constant, A., and Shchmurove, Y. (2006). Entrepreneurial ventures and wage differentials between Germans and immigrants. International Journal of Manpower, 27(3), 208-229.

Dalziel, M. (2008). Immigrants as Extraordinarily Successful Entrepreneurs: A Pilot Study of the Canadian Experience. Journal of Small Business and Entrepreneurship, 21(1), 23-36. 
Danes, S., Lee J., Stafford, K., and Heck, R.K. (2008). The effects of ethnicity, families and culture on entrepreneurial experience: an extension of sustainable family business theory. Journal of Development Entrepreneurship, 13 (3), 229-268

Davenport,T.H., and Prusak, L. (1998). Working knowledge: How organisations manage what they know. Boston: Harvard Business School Press.

Davidsson, P., and Honig, B. (2003). The role of social and human capital among nascent entrepreneurs. Journal of Business Venturing, 18(3), 301-331.

Deakins, D., Majmuda, M., and Paddison, A. (1997). Developing success strategies for ethnic minorities in business: evidence from Scotland. New Community, 23(3), 325-42.

Deakins, D., Ishaq, M., Smallbone, D., Whittam, G., and Wyper, J. (2007). Ethnic Minority Businesses in Scotland and the Role of Social Capital. International Small Business Journal, 25 (3), 307-322.

Dhaliwal, S. (2006). The take-up of business support by minority ethnic enterprises: The experience of South Asian business in England. The International Entrepreneurship and Management Journal, 2(1), 79-91.

Dierickx, I., and Cool, K. (1989). Asset stock accumulation and sustainability if competitive advantage. Management Science, 35(12), 1505-1513.

Eisenhardt, K.M., and Santos, F.M. (2001). Knowledge-based view: A new theory of strategy? In A. Pettigrew, H. Thomas \& R. Whittington (Eds.), Handbook of strategy and management. London: Sage Publications.

Ekanem, I., and Wyer, P. (2007). A fresh start and the learning experience of ethnic minority entrepreneurs. International Journal of Consumer Studies, 31(2),144-151.

Fadahunsi, A., Smallbone, D., and Supri, S. (2000). Networking and ethnic minority enterprise development: Insights from a North London study. Journal of Small Business and Enterprise Development, 7(3), 228-240.

Fahey, L., and Prusak, L. (1998). The eleven deadliest sins of knowledge management. California Management Review, 40: 265-276.

García, Rodríguez, F.J., Gutiérrez, Taño, D., Baute Díaz, N., and Díaz Armas, R. (2006). La emprendeduría en el colectivo de personas inmigrantes: Contextualización, importancia y oportunidades. Investigación y Marketing, 90, 5-10.

Grant, R.M. (1996). Prospering in dinamically-competitive environments: Organizational capability as knowledge integration. Organization Science, 7, 375-387.

Grant, R.M. (2002). Strategy Analysis. Concepts, techniques, applications. Oxford: Blackwell.

Hackler, D., and Mayer H. (2008). Diversity, entrepreneurship, and the urban environment. Journal of Urban Affairs, 30(3), 273-307.

Hammarstedt, M. (2001). Immigrant self-employment in Sweden - its variation and some possible determinants. Entrepreneurship \& Regional Development, 13, 147-161.

Hart, M.M., Stevenson, H.H., and Dial, J. (1995). Entrepreneurship: a definition revisited. Frontiers of Entrepreneurship Research. Babson College, Wellesley, MA.: 75-89

Hormiga, E., Batista Canino, R.M., and Sánchez Medina, A. (2008). El capital intelectual en las empresas de nueva creación. Influencia de los activos intangibles en el éxito empresarial. Santa Cruz de Tenerife: Fundación FYDE-Cajacanarias.

Jamal, A. (2005). Playing to win: An explorative study of marketing strategies of small ethnic retail entrepreneurs in the UK. Journal of Retailing and Consumer Services, 12, 1-13

Jones, T., and Ram, M. (2007). Re-embedding the ethnic business agenda. Work, employment and society, 21(3), 439-457.

Kalnins, A., and Chung, W. (2006). Social Capital, Geography, and Survival: Gujarati Immigrant Entrepreneurs in the U.S. Lodging Industry. Management Science, 52(2), 233-247.

Killian, C., and Johnson, C. (2006). 'I'm not an immigrant': Resistance, redefinition, and the role ofn resources in identity work. Social Psychology Quarterly, 69(1), 60-80.

Leonard, D., and Sensiper, S. (1998). The role of tacit knowledge in group innovation. California Management Review, $40,112-132$. 
Levent, T.B., Masurel, E., and Nijkamp, P. (2003). Diversity in entrepreneurship: ethnic and female roles in urban economic life. International Journal of Social Economics, 30(11), 1131-1161.

Ley, D. (2006). Explaining variations in business performance among immigrant entrepreneurs in Canada. Journal of Ethnic and Migration Studies, 32(5), 743-764.

Mirsky, J., Slonim-Nevo, V., and Rubinstein, L. (2007). A four-year longitudinal study in Israel and Germany. International Migration, 45(1), 151-175.

Nonaka, I., and Takeuchi, H. (1995). The knowledge-creating company. New York: Oxford University Press.

Nonaka, I., and Teece, D.J. (2001). Introduction. In I. Nonaka and D.J. Teece (Eds.), Managing industrial knowledge. Creation, transfer and utilization. London: Sage Publications.

North, D.C. (1991). Institutions. Journal of Economic Perspectives, 5(1), 97-112.

Pfeffer, J., and Slancik, G.R. (2003). The External Control of Organizations: A resource dependence perspective. New York: Harper \& Row.

Porter, M. (1985). Competitive advantage: creating and sustaining superior performance. New York: Free Press.

Portes, A. (1987). The social origins of the Cuban enclave economy of Miami. Sociological Perspectives, 30, 340-72.

Raijman, R. (2001). Determinants of entrepreneurial intentions: Mexican immigrants in Chicago. Journal of Socio-Economics, 30, 393-411.

Ram, M. (1994). Unravelling social networks in ethnic minority firms. International Small Business Journal, 12(3), 42-53.

Rath, J. (2007). The transformation of ethnic neighborhoods into places of leisure and consumption. San Diego: Center for Comparative Immigration Studies University of California. Working Paper 144.

Reed, R., and DeFillipi, R. (1990). Causal ambiguity, barriers to imitation, and sustainable competitive advantage. Academy of management Review, 15, 88-102.

Rumelt, R. (1984). Towards a strategic theory of the firm. In R. Lamb (Eds.), Competitive strategic management. Englewood Cliffs: Prentice-Hall.

Rumelt, R. (1987). Theory, strategy and entrepreneurship. In D. Teece, D. (Eds.), The competitive challenge: Strategies for industrial innovation and renewal. Cambridge: Ballinger.

Rusinovic, K. (2008a). Moving between markets? Immigrant entrepreneurs in different markets. International Journal of Entrepreneurial Behaviour \& Research, 14(6), 440-454.

Rusinovic, K. (2008b). Transnational embeddedness: Transnational activities and networks among first- and second-generation immigrant entrepreneurs in the Netherlands. Journal of Ethnic and Migration Studies, 34(3), 431-451.

Sáiz López, A. (2004). La migración china en España. Características generales. Revista CIDOB d'Afers Internacionals, 68, 151-163.

Saxenian, A. (2006). The new argonauts: Regional advantage in a global economy. London: Harvard University Press.

Sequeira, J.M., and Rasheed, A.A. (2006). Start-up and growth of immigrant small businesses: The impact of social and human capital. Journal of Developmental Entrepreneurship, 11(4), 357-375.

Shane, S. (2000). Prior knowledge and the discovery of entrepreneurial opportunities. Organization Science, 11(4), 448-469.

Shinnar, R.S., and Young, C.A. (2008). Hispanic immigrant entrepreneurs in the Las Vegas Metropolitan Area: Motivations for entry into and outcomes of self-employment. Journal of Small Business Management, 46(2), 242-262.

Sorenson, O., and Singh, J. (2007). Science, Social Networks and Spillovers. Industry and Innovation, 14(2), 219-238.

Sriram, V., Mersha, T., and Herron, L. (2007). Drivers of urban entrepreneurship: an integrative model. International Journal of Entrepreneurial Behaviour \& Research, 13(4), 235-251.

Teece, D.J. (1998). Research directions for knowledge management. California Management Review, 40(3), 289-292.

Tienda, M., and Raijman, R. (2004). Promoting hispanic immigrant entrepreneurship in Chicago. Journal of Developmental Entrepreneurship, 9(1), 1-21. 
Tsoukas, H., and Vladimirou, E. (2001). What is organizational knowledge? Journal of Management Studies, 38, 973-993.

Turan, M., and Kara, A. (2007). An exploratory study of characteristics and attributes of Turkish entrepreneurs: A cross-country comparison to Irish entrepreneurs. Journal of International Entrepreneurship, 5(1-2), 25-46.

Vinogradov, E., and Kolvereid, L. (2007). Cultural background, human capital and self-employment rates among immigrants in Norway. Entrepreneurship \& Regional Development, 19, 359-376.

Volery, T. (2007). Ethnic entrepreneurship, a theorical framework. In L. Dana (Eds.), Handbook of research on ethnic minority entrepreneurship. Northampton: Edward Elgar Publishing, Inc.

Waldinger, R., Aldrich, H.E., and Ward, R. (1990). Immigrant Entrepreneurs: Immigrant and Ethnic Business in Western Industrial Societies. Beverly Hills: Sage Publications.

West III, G.P., and Noel, T.W. (2009). The impact of knowledge resources on new venture performance. Journal of Small Business Management, 47(1), 1-22.

Wiklund, J., and Shepherd, D. (2003). Knowledge-based resources, entrepreneurial orientation, and the performance of small and medium-sized businesses. Strategic Management Journal, 24, 1307-1314.

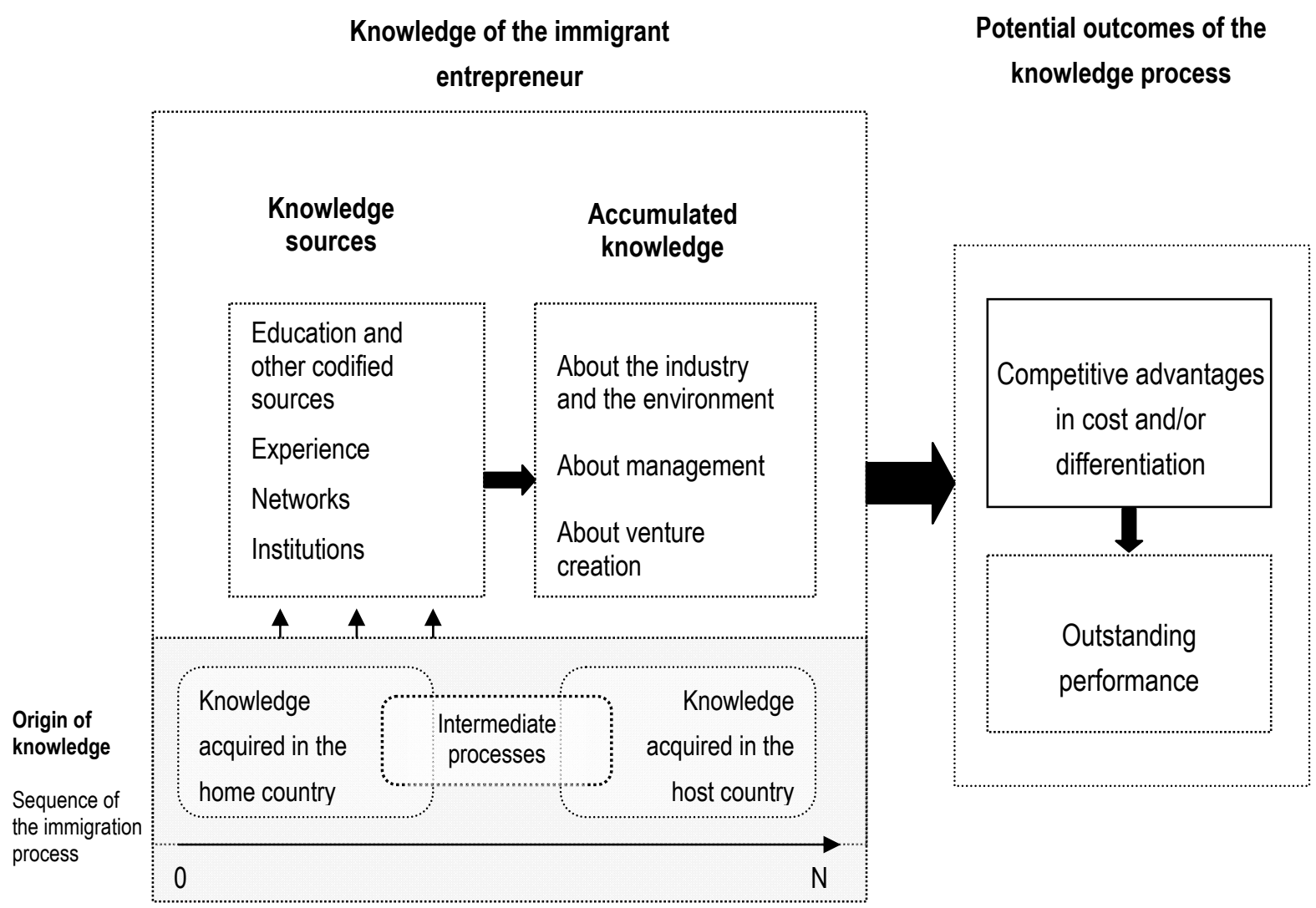

Figure 1. Knowledge generation in the immigrant entrepreneurial process

Source: Own elaboration 